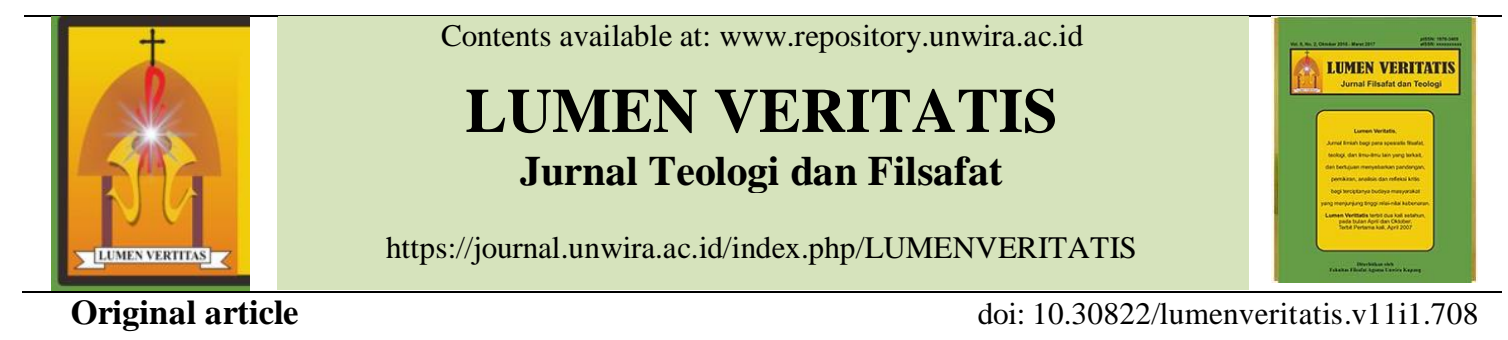

\title{
PENGETAHUAN AKAN ALLAH: ANTARA IMPOSSIBILITAS DAN SURPASSIBILITAS
}

\author{
Oktovianus Naif \\ Program Studi Ilmu Filsafat, Fakultas Filsafat Universitas Katolik Widya Mandira \\ Jl. Prof. Dr. Herman Yohanes - Penfui - Kupang - NTT \\ Email: naifokto@gmail.com
}

\begin{abstract}
Man and woman are created in God's image so they have desire to know their Creator and they also need God in their lives which causes the desire to know Him. The desire in question, then, is a desire to understand God. For the desire is prior to knowing and it is compatible with not knowing. It is true if we say that man's unrestricted desire to know is mated to a limited capacity to attain knowledge about Him.For its finiteness human capabilitycould not get hold of a complete knowledge of God.In knowing God and aknowledging Him as Being of beings, human beings must be aware of his ignorance that is "the only true wisdom is in knowing I know nothing." God, therefore, takes the first step to contact with human beings, then He reveals Himself, He gives Himself to be known and He makes Himself known by human beings. This is a self-manifestation of Someone to someone. Revelation is due to the intiative of God that is God reveals Himself, when He wills, to whom He wills and because He wills. God's revelation illuminates the intellectual capabilityof humans so that human beings are able to know Him and aknowledge Him and talk about Him as Being of beings. Knowledge of God is called theology. Ultimately, theology is about God in Himself. Thus, theology is the peak of knowledge and the fullness of gnosis since it was brought about under the guidance of the Spirit.So, we could say, God makes knowledge possible for human beings and God is really the Possibler of knowledge and aknowledge of Himself.
\end{abstract}

Keywords: Ingin tahu, Akal budi terbatas, Allah the Possibler pengetahuan

\section{Pendahuluan}

Salah satu diktum kondang Aristoteles dalam Metaphysics ialah all men by nature desire to know. ${ }^{1}$ Motto periode Aufklärung ialah sapere audeberanilah mengetahui seperti dikatakan I. Kant dalam Answering the Question:

1 Samuel E. Stumpf, Philosophy. History \& Problems, (New York: McGraw-Hill, Inc, 1989), 88

2 Immanuel Kant, what is Enlightenment? translated and edited by Lewis White Beck (Indianapolis: Bobbs-Merrill, 1959), 85
What is Enlightenment? ${ }^{2}$ Tujuan proyek Pencerahan ialah membangun peradaban berdasarkan rasio murni dan fakta empiris terukur dan terbukti sekaligus meniadakan Allah dari hidup manusia. ${ }^{3}$ Dengan demikian, knowledge is power, kata F. Bacon ketika berbicara tentang the utility of knowledge. Pengetahuan harus

${ }^{3}$ Uraian detail tentang pola pikir rasionalistik murni ini bisa ditemukan dalam karya James W. Sire, The Universe Next Door, Edisi 3 (Downers Grove, III: InterVarsity Press, 1997), bab 1-4 
dibebaskan dari teks-teks klasik dan kebenaran ilmiah harus dipisahkan dari kebenaran yang direvelasikan seperti yang dibicarakan dalam teologi. ${ }^{4}$ Para pemikir abad Pencerahan percaya bahwa manusia bisa mengetahui apa saja, sebaliknya kaum Postmodernis yakin bahwa manusia tak bisa mengetahui apapun. ${ }^{5}$

Dalam nada moderat T.S. Eliot mengatakan bahwa manusia bisa mengetahui sesuatu namun ia tak bisa mengetahui segala sesuatu. Jumlah keingin-tahuan manusia tak terbatas namun humankind cannot bear very much reality-manusia manapun tak mampu menampung semua realitas di dalam akal budinya. ${ }^{6}$ Man's unrestricted desire to know is mated to a limited capacity to attain knowledge $e^{7}$ keingintahuan manusia yang tak terbatas ada bersamaan dengan keterbatasan kemampuan akal budi untuk meraih pengetahuan. Principiumrationis (G.W Leibniz) adalah prinsip yang terbatas atau il pensiero è debole - akal budi itu lemah dan karena itu akal budi menghasilkan il

${ }^{4}$ Samuel Enoch Stumpf, Op. Cit., 221

${ }^{5}$ Edward O. Wilson, Consilience: The Unity of Knowledge (New York: Knopf, 1988), 8

${ }^{6}$ Thomas Stearns Eliot, Murder in the Cathedral, (New York: Brace \& World, Harcourt, 1963), 69

${ }^{7}$ Bernard Lonergan, Insight: A Study of Human Understanding, edited by Frederick E. Corwe and Robert M. Doran, (Toronto: University Toronto Press, 1992), 662: “...From this paradox there follow both a fact and a requirement. The fact is that the range of possible questions is larger than the range of possible answers. The requirement is a critical survey of possible questions. For it is only through such a critical survey that man can provide himself with intellegent and reasonable grounds both for setting aside the questions that can not be answered and for limiting his attention to the questions to which answers are possible. Lihat juga Stephen B. Bevans, Teologi Dalam pensiero debole - ide terbatas (Gianni Vattimo). "Akal budi manusia tidak dapat - karena naturanya - mencapai sebuah solusi definitif dan absolut..." 8 Pengetahuan terbaik tentang Allah adalah docta ignorantia.

Melampaui kerapuhan berpikir manusia dan fluktuasi pasar paham teologis, ada audit Allah. Di bawah audit Allah akan ada perbaikan dan penajaman pemikiran teologis kita.

\section{Yang terbatas berpikir tentang Yang Tak Terbatas}

"Hidup yang tak dipikirkan adalah hidup yang tak layak dijalani”. Pernyataan tenar ini konon diucapkan oleh Socrates pada saat pengadilannya atas tuduhan menentang dewa dan merusak generasi muda, yang kemudian membuatnya dijatuhi hukuman mati. ${ }^{9}$

Yang harus dipikirkan lebih dahulu sebelum kita berpikir tentang arti kehidupan ialah thinking on thinking berpikir tentang berpikir, demikian kata Aristoteles. ${ }^{10}$

Perspektif Global, (Maumere: Penerbit Ledalero, 2010), 49

8 Dario Antiseri, "La Conoscenza Filosofica" dalam Giovanni Reale, Dario Antiseri, Quale Ragione (Milano: Rafaello Cortina Editore, 2001), 111: "La ragione umana non possa - per natura - giungere a soluzione definitive, assolute..."; Lihat Felix Baghi, "Ambang Batas Rasio Dan Pengetahuan: Kemungkinan Bagi Iman (Pendasaran Etik-Metafisis Untuk Iman)" dalam Paul Budi Kleden dan Robert Mirsel (editor), Menerobos Batas, Merobohkan Prasangka Jilid 2 (Maumere: Penerbit Ledalero 2011), 67-90

${ }^{9} \mathrm{http}$ //id.wikipedia org/wiki/pengadilan socrates. Diakses 29 Agustus 2020, pukul 21.35. ó ...

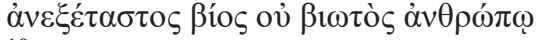

10 Dikutip oleh Fung Yu - Lan dalam Sejarah Filsafat Cina (Yogyakarta: Pustaka Pelajar, 2007), 3-4 
René Descartes menganggap segala sesuatu adalah ilusi kecuali berpikir: "saya tak bisa memiliki keraguan apapun bahwa saya berpikir...cogito ergo sum."

Seperti Descartes, B. Pascal memiliki passion berpikir: "manusia hanyalah sebatang buluh...tetapi ia adalah sebatang buluh yang berpikir."12 Kata Pascal, "si mistik hexagram" dalam kumpulan aforismenya Pensées: "manusia jelas dijadikan untuk berpikir. Di sanalah terletak seluruh martabat dan nilai kebaikannya; seluruh tugasnya ialah berpikir sebagaimana seharusnya. Tatanan pemikiran adalah mulai dengan diri kita sendiri, dan dengan Allah Pencipta kita dan tujuan akhir kita."13

Ternyata Allah tak saja diimani tetapi juga dipertanyakan adaNya oleh homo quarens. Ada sejumlah questionis disputatis: bisakah manusia mengetahui yang Mahatahu? Mengapa manusia percaya akan Allah? Apakah Allah ada? Benar bahwa:

Hidup ini ditandai oleh banyak tanya tetapi juga dilingkari oleh cahaya, cinta dan kehadiran Allah: Allah beserta kita. Apakah kita beserta Allah dan mengenali kehadiranNya? Allah ada bukan sebagai ide melainkan sebagai Ada. Dia

11 Samuel E. Stumpf, Philosophy: History \& Problems (New York: McGraw-Hill, Inc. 1989), 242-243

${ }^{12}$ Hans Küng, Does God Exist? An Answer for Today (New York: Crossroad 1978), 45: "Man is only a reed...but he is thinking reed"

13 "L'homme est visiblement fait pour penser. C'est tou sa dignité et tout son mérite; et tout son devoir est de penser comme il faut. Or l'ordre de la pensée est decommencer par soi, et par son auteur et sa fin." Lihat, Giuliano Vigini, Pascal: Verso l'Infinito di Dio. Brani Scelti dai Pensieri e da altri Scriti. Traduzione, introduzione e scelta dei brani di Giuliano Vigini (Milano: Paoline Editoriale Libri, 1997), 146 /620), 57; Alban J. Krailsheimer, Pascal: Pensées, Introduction and dekat padamu lebih dekat daripada hatimu. Dia di dasar sadarmu dan di balik tak sadarmu. Dia selalu ada padamu. Dia Temanmu tanpa kau-temu. Dia Allahmu tanpa kau tahu. ${ }^{14}$

Demi mengetahui Allah, manusia mencari Allah, ${ }^{15}$ dan menalar Allah. ${ }^{16}$ Manusia memaksimalkan rasionya bukan demi mencari Ab-grund (suatu kesiasiaan) atau Un-grund (sesuatu yang tanpa alasan) melainkan demi mengetahui $U r$ grund atau dasar terdalam dari adanya yang tak ia miliki di dalam dirinya sendiri. ${ }^{17}$

Keingin-tahuan akan Allah tak selalu terpuaskan karena kandas di batas nalar. Bisa terjadi bahwa di ujung pencariannya, manusia hanya bersua dengan nothing atau no-thing: "Allah itu segalanya dalam DiriNya sendiri, tetapi adalah ketiadaan dari segalanya bagi diri kita. Allah itu cahaya pada DiriNya sendiri, tetapi adalah kegelapan bagi diri kita. Allah itu kepenuhan pada DiriNya sendiri, tetapi adalah kekosongan bagi diri kita." 18

Di sini, kerendahan hati intelektual amat penting: scio me nihil scire Visi teologis seorang teolog ialah visi teologis

translation (Baltimore: Penguin Books 1966), 620/146, 235.

14 Pius Budiwijaya, Tuhan Memegangku (Yogyakarta: Penerbit Kanisius, 1989), 91

15 Theo Huijbers, Mencari Allah (Yogyakarta: Penerbit Kanisius, 1992)

16 Franz Magnis-Suseno, Menalar Tuhan (Yogyakarta, Penerbit Kanisius, 2006)

17 Dikutip oleh Jozef Pieniazek di dalam tulisannya yang berjudul "Soal Pemberian Dalam Terang Refleksi Metafisis," dalam Frans Ceunfin \& Felix Baghi, Mengabdi Kebenaran, (Maumere: Penerbit Ledalero, 2005), 330

${ }^{18}$ William Johnston, Teologi Misitk (Yogyakarta: Penerbit Kanisius, 2001), 155 
yang rendah hati. Jalan menuju ke pengetahuan ialah rendah hati, rendah hati, rendah hati ${ }^{19}$ dan terbuka bagi perbaikan demi terpeliharanya kesetiaan pada Kitab Suci dalam teologinya dan

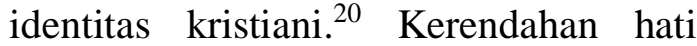
mengajarkan pengetahuan, kesombongan mengajarkan kebodohan. Keangkuhan intelektual merupakan sebuah bentuk cognitive suicide.

Betapapun keterbatasan nalar adalah fakta natural, namun sebagai a knowing being manusia beriman dalam iman terus mencari untuk mengetahui dan mengetahui untuk terus menerus mencari Allah. Untuk suksesnya pencarian dan pengenalan akan Allah, dibutuhkan teologi personalistik/interpesonal atau relasi personal dengan Sumber Pengetahuan.

${ }^{19}$ William A. Kaschmitter, The Spirituality of the Catholic Church, (Texas: Lumen Christi Press 1982), 513; Kosuke Koyama, Water Buffalo Theology, (New York: Maryknoll, Orbis Books, 1999), 142; Stephen B. Bevans, Teologi Dalam Perspektif Global, (Maumer: Penerbit Ledalero, 2010), 54

20 Robert J. Schreiter, Constructing Local Theologies, (New York: Maryknoll, Orbis Books, 1985), 117-121. Robert J. Schrieter mengemukakan lima kriteria untuk menegaskan kesetiaan berteologi dan identitas kristiani. "...the five criteria for establishing Christian identity. The five criteria have to work in consort....all five are needed to arrive at a positive decision. The five are in fact well-known ones in the tradition... The first criterion: the cohesiveness of Christian performance; te secon criterion: the worshiping context and Christian performance; the third criterion: the praxis of the community and Christian Performance; the fourt criterion: the judgement of other Churches and Christian performance; the fifth criterion: the challenge to other Churches and Christian perfomance."

\section{Pentingnya teologi yang bersifat personalistik}

Teologi itu pengetahuan tentang divinitas. ${ }^{21}$ Disebut teologi karena topik pokok diskursusnya ialah Allah. ${ }^{22}$ Apakah Allah itu subyek atau obyek pemikiran teologis? Teologi, kata René Latourelle, adalah diskursus atau pembicaraan tentang Allah atau pengetahuan yang menjadikan Allah sebagai obyeknya. ${ }^{23}$ Statemen teologis ini tidak diiyakan oleh Stanley Jedida Samartha dengan mengatakan bahwa Allah tak pernah menjadi obyek pengetahuan manusia. Allah selalu menjadi subyek abadi pengetahuan manusia. $^{24}$ Para teolog tidak patut menjadikan Allah sebagai sebuah 'obyek' dalam arti ilmiah yakni meletakkan Allah di depan mata, mengukur, menghitung, mengkaji kontur-kontur dan menyimpulkan secara intelektual. Allah itu selalu subyek dan

${ }^{21}$ St. Agustinus, La Città di Dio, (Roma: Città Nouva Editrice 1997), VIII. 1: "Teologia, parola greca, con cui s'intende indicare il pensiero ossia il discorso sull'esistenza e la provvidenza della divinità."

${ }^{22}$ St. Thomas Aquinas, Summa Theologia, I, q. 1, a. 7: "in hac scientia fit sermo de Deo: dicitur enim theologia, quasi sermo de Deo."

23 René Latourelle, Theology, Science of Salvation, (New York: Alba House, 1969), 3; Stephen B. Bevans, Op. Cit., 11 dan footnote 2: Lebih tepat kiranya bila R. Latourelle mengatakan bahwa teologi adalah pengetahuan akan Allah dalam arti ganda yakni teologi adalah pengetahuan yang Allah miliki tentang DiriNya sendiri (pengetahuan dari Allah) dan teologi adalah pengetahuan yang manusia miliki tentang Allah.

${ }^{24}$ Stanley Jedida Samartha, "The Asian Context: Source and Trends" dalam Rasiah S. Sugirtharajah, (Ed), Voices from the Margin: Interpreting the Bible in the Third World, (New York: Orbis Books, 1991), 48 
selalu merupakan misteri ${ }^{25}$ dan God ever the greater than apapun yang dipikirkan oleh manusia tentangNya. Deus semper major. $^{26}$

Pemikiran, pengetahuan dan pembicaraan tentang Allah adalah pemikiran, pengetahuan dan pembicaraan tentang Subyek. Teologi yang bermaksud untuk mengetahui dan membicarakan Allah setulus-tulusnya, harus bersifat personalistik yakni bertolak dari Allah sebagai Persona dan berlanjut kepada relasi personal dengan Allah. Allah sebagai Pribadi lebih dahulu berinisiatif menjalin relasi interpersonal atau membangun struktur dialog dengan manusia. Dialog intim antara manusia dan Allah itu bisa disebut salutis colloquium karena berkarakter redemptif. Melalui pergaulan yang intens itu, manusia makin tahu bahwa Allah melampaui apapun dan siapapun dan serentak juga manusia makin insaf bahwa Allah itu lebih dekat dalam hatinya daripada dirinya sendiri. Jadi, pengetahuan manusia tentang Allah dan dirinya sendiri bertambah-tambah dalamnya karena keakraban denganNya sebagai Persona. Allah yang dikenal itu dibicarakan dan pembicaraan itu merupakan suatu forma pewartaan meriah tentang Allah. Pikiran dan kehendak Allah yang diketahui dan dibicarakan patut dihayati sehingga hal

${ }^{25}$ Ronaldo Muños, The God of Christians, (New York: Maryknoll, Orbis Books, 1990), 4

26 Joseph H.P. Wong, Logos-Symbol in the Christology of Karl Rahner (Roma: Libreria Ateneo Salesiano, 1984), 105

27 Paus Paulus VI, Evangelli Nuntiandi, Anjuran Apostoli (tanggal 8 Desember tahun 1975) dalam Seri Dokumen Gerejawi 6 (Jakarta: Departemen Dokumentasi dan Penerangan KWI, 2005), No. 21

28 Theo Huijbers, Op. Cit., 95-96 itu dapat dipandang sebagai sebuah kesaksian meyakinkan akan kasih Allah. Kesaksian hidup itu secara silence dan effective dapat memberitakan kabar gembira kepada sesama ${ }^{27}$ bahkan karenanya, orang lain dapat merasa tertarik dan terundang untuk mengambil bagian dalam menghayati hidup secara mendalam dan menerima Allah sebagai Allah yang hidup dan menghidupkan serta sumber kelimpahan hidup. ${ }^{28}$

Manusia memiliki hidup dan mempunyainya dalam segala kelimpahan (Yoh 10:10) karena manusia setia kepada Allah. Kata Sta. Teresia dari Yesus: “.... kesabaran dan kesetiaan memperoleh segala sesuatu. Siapa yang memiliki Allah tak kekurangan sesuatupun. Allah sendiri mencukupi". ${ }^{29}$ Refleksi spiritual itu dikukuhkan oleh Kitab Wahyu: "Hendaklah engkau setia sampai mati, dan Aku akan mengaruniakan kepadamu mahkota kehidupan" (Why 2:10). Oleh sebab itu, rester fidèle à ce qu'on fut, tout reprender par le début ${ }^{30}$ - tetaplah setia pada apa yang telah dipilih dan ambillah sekali lagi (pilihlah sekali lagi) pilihan itu mulai dari awal. Apapun bentuk keruwetan hidup hendaknya kesetiaan pada pilihan iman kita tidak luntur. "Tinggalkan sesuatu bagi Allah tetapi jangan meninggalkan Allah karena sesuatu". Tanpa Allah mana tahan...bila ciptaan mengabaikan Pencipta berarti

\footnotetext{
${ }^{29}$ Yohanes Paulus II (Promulgator), Katekismus Gereja Katolik, diterjemahkan oleh Herman Embuiru, Katekiskmus Gereja Katolik (Ende, Percetakan Arnoldus 1995) no.227. Selanjutnya akan disingkat $K G K$ dan diikuti nomor artikel.

30 Maurice Merleau-Ponty, Signes, (Paris: Gallimard, 1960), 12; ide ini dikutip oleh William J. Hill, dalam bukunya, The Three Personal God, (Washington: The Catholic University of America Press, 1982), ix
} 
ciptaan itu hidup dalam kegelapan. Tanpa Pencipta, makluk ciptaan lenyap menghilang. ${ }^{31}$ Allah minus dunia $=$ Allah . Dunia minus Allah $=$ Nihil.$^{32}$

Allah itu Maha-Ada dan semua ada lainnya mengambil bagian dalam adaNya supaya yang ada, ada dalam hidup yang berkelimpahan karena gloria Dei, homo vivens - kemuliaan Allah adalah manusia yang hidup (Irenius) dan hidup dalam segala kelimpahan (Yoh 10:10) spiritual dan intelektual. Kemudian, dengan kerendahan hati dan kesadaran utuh kita mempersembahkan kembali segala kekayaan rohani dan semua perbendaharaan intelektual kita ad majorem Dei gloriam (Ignatius d'Loyola). Motto ad maiorem Dei gloriam pada akhirnya berujung pada kesadaran akan Allah sebagai Deus semper major dan pengalaman transendental akan Allah sebagai ever greater of possibilities. ${ }^{33}$

\section{Kekusutan dalam pengetahuan dan pembicaraan tentang Allah}

Secara umum kita menemukan kekusutan empat dimensi pengetahuan atau konklusi yang saling silang yakni 1) Allah itu ada atau tiada, itu sulit dipastikan; 2) Allah memang tidak ada. 3) Allah ada tetapi tidak bisa diketahui dan

\footnotetext{
${ }^{31}$ Konsili Vatikan II, Gudium et Spes, Konstitusi Pastoral tentang Gereja di Dunia Dwasa Ini (tanggal 7 bulan Desember 1965), dalam R Hardawirjana (pener.), Dokumen Konsili Vatikan II (Jakrta: Obor, 1993), no. 36. Untuk kutipan selanjutnya, akan dipakai singkatan $G S$ diikuti nomor artikel.

32 Ronald H. Nash, Iman dan Akal Budi, (Surabaya: Penerbit Momentum, 1988), 188

${ }^{33}$ Joseph H.P. Wong, Op. Cit, 104

34 Theo Huijbers, Op. Cit., 15

${ }^{35}$ William Johnson, Teologi Mistik. Ilmu Cinta, (Yogyakarta: Penerbit Kanisius, 2001), 35
}

dibuktikan adanya secara rasional; 4) Allah ada dan adanya Allah bisa diketahui dan juga bisa dibuktikan secara rasional. ${ }^{34}$

Kekusutan empat dimensiini termasuk dalam ranah misteri. Allah direlasikan dengan kata misterio (diam) $)^{35}$ sedangkan manusia dikaitkan dengan kata misera (hina dina) karenaInter creatorem et creaturam non potest (tanta) similitude notari, quin inter eos maior sit dissimilitude notanda - antara Pencipta dan ciptaan tak bisa tercatat sesuatu kemiripan (yang begitu besar) tanpa menulis sebuah ketakmiripan yang jauh lebih besar di antara Pencipta dan ciptaan atau in tanta similitudine, sed maior dissimilitudo - dalam sebuah kemiripan yang begitu besar, ada sebuah ketakmiripan yang jauh lebih besar lagi. ${ }^{36}$ Ada perbedaan kualitatif antara Allah dan manusia:

"Allah adalah adamu dan di
dalam Dia kamu adalah kamu
seperti apa adamu, tidak hanya
berkat kedudukanNya sebagai
penyebab dan berkat adamu
dan menjadi adamu...
senantiasa mempertahankan
perbedaan antara kamu dan Dia
sehingga Dia adalah adamu
tetapi kamu bukan adaNya. ${ }^{37}$

$36 K G K$, no. 43; Giovanni Marchesi, La Cristologia Trinitaria, Cristologia Trinitaria di Hans Urs Von Balthasar, (Brescia: Editrice Queriniana, 1997) 223-238; Giovanni Marchesi, "Il mistero di Dio nella riflessione teologica di Jurgen Moltman" dalam Civiltà Cattolica III (1985), 254-266J; Josepho Alberigo et alii (curantibus), Conciliorum Oecumenicorum Decreta, (Bologna: Istituto Scienze Religiose, 1973), 232; Julio Terán Dutari, Christentum und Metaphysik. Das Verständtnis Beider Nach der Analogielehre Erich Pryzwara, (München 1973), 572-585

${ }^{37}$ William Johnson, Op. Cit., 49 


\section{The possible of knowledge}

Nampaknya paradoks tertinggi dari seluruh pemikiran teologis ialah mengetahui sesuatu yang tidak dapat dipikirkan oleh pikiran. Menurut il Cusano (Nikolaus dari Cusa), Allah itu complicatio dari segala sesuatu, explicatio-Nya ialah ketidak-tuntasan penjelasan tentangNya dan ketakterbatasanNya ialah konsiliasi dari coincidentia oppositorum. ${ }^{38}$ Kita 'mempelajari' Dia untuk mengakui ketaktahuan kita tentang Dia yang melampaui akal budi manusia tercerdas, tentang Trinitas yang melampaui semua penjumlahan dan penomoran manusia, tentang kesempurnaan ilahi yang melampaui segala yang terbaik. ${ }^{39}$

Tidak sanggup tahu, lebih baik memilih silentium mysticum

Waktu St. Thomas Aquinas harus menegaskan nama Allah, ia memilih nama: Qui Est dan dia mengacu kepada 'EH'YEH'ASYER EH'YEH (Kel 3:1315). ${ }^{40}$ Allah dan namaNya adalah misteri EGÔ EIMI HO ÔN namun bersamaan dengan itu pula Ia menghadiahkan kehadiranNya kepada manusia: "Aku selalu menyertai kamu". ${ }^{4}$ Ini bukan dialektika antitesis (Gott-über-in Geschöpf) tetapi ini adalah realitas bahwa Allah, di satu sisi mengatasi dunia secara

382000 Teologi Cattolici, Ortodossi, Protestanti, Lexicon, Dizionario Dei Teologi Dal Primo Secolo Ad Oggi (Casale Monferrato: Edizione Piemme Spa, 1998), 346

39 Stephen B. Bevans, Op. Cit. 15; David L. Edwards, Christianity: The First Two Thousand Years (Maryknoll, New York: Orbis Books, 1997), 261.

${ }^{40}$ Thomas Aquinas, Summa Theologiae, I, q. 13, a. 11: "QUI EST est maxime proprium nomen Dei"

${ }^{41} K G K$, no. 205-206. menyeluruh namun di lain sisi Allah present in andgreater than anything. ${ }^{42}$

Allah itu mystheon-diam. Bukankah jauh lebih logis kita menutup mulut berkaitan dengan Allah daripada membicarakan Allah? Bukankah jauh lebih mulia mengamini Tiga dengan rendah hati dan mentahtakanNya di inti hidup kita dan mewartakan bahwa Trinitas adalah incomprehesible, unknowable, ineffable daripada berdiskursus dan berdiskusi tentang Tiga yang bisa berpotensi salah teropong, salah pikir dan salah bicara tentangNya?

Allah itu sejatinya memang Diam yang berkata-kata. Bersua dengan Diam (encounter with Silence) yang bersabda, manusia layak memilih sikap diam untuk mendengar (Worte ins Schweigen. Gebete der Einkehr). ${ }^{43}$ Sesungguhnya apa yang terletak di luar jangkauan kata-kata, itu adalah ungkapan terfasih tentang Allah. ${ }^{44}$

Keterbatasan akal budi dalam mengetahui dan membicarakan Allah membuktikan bahwa Allah itu melampaui akal budi tercerdas manapun juga. $^{45}$ Setiap gagasan teologis mengandung potential falsifier dan berada di zona partial, falible dan criticable. Kemampuan akal budi tak membebaskan manusia dari fakta bahwa akal budinya bisa diragukan. ${ }^{46}$

Walau akal budi manusia, melalui kekuatan kodrati dan

${ }^{42}$ Joseph H.P. Wong, Op.Cit., 105-206

${ }^{43}$ Joseph H.P. Wong, Op. Cit., 104

44 George Steiner, Language and Silence, (London: SCM Press, 1967), 58-59

${ }^{45}$ George Stainer, Op. Cit., 58-59

${ }^{46}$ Joseph Ratzinger, "Apa Yang Mempertahankan Keutuhan Dunia. Dasar-dasar Moral Prapolitis Sebuah Negara Liberal" dalam Paul Budi Kleden dan Adrianus Sunarko (Eds), Dialektika Sekularisasi, Diskusi Habermans - Ratzinger dan Tanggapan, (Maumere: Penerbit Ledalero dan Penerbit Lamalera, 2010), 42 
sinarnya benar-benar dapat sampai kepada pengertian yang benar dan pasti mengenai satu Allah yang berkepribadian, yang melindungi dan membimbing dunia ini dengan penyelenggaraannya, namun terdapat pula halangan yang tidak sedikit bahwa akal budi itu akan mempergunakan secara berdaya guna dan berhasil, kemampuan yang merupakan bakat pembawan sejak lahir. Karena kebenaran yang menyangkut Allah serta hubungan antara Allah dan manusia sungguh melampaui tata dunia yang kelihatan; kalau diterapkan pada cara hidup manusia untuk membentuknya, maka kebenaran-kebenaran itu akan menuntut pengurbanan diri dan penyangkalan diri. Akan tetapi, akal budi manusia mengalami kesulitan dalam usahanya untuk mencari kebenarankebenaran yang demikian itu, bukan hanya karena dorongan pancaindra dan khayalan, melainkan juga karena nafsu yang salah, yang merupakan akibat dari dosa asal. Maka terjadilah bahwa manusia dalam hal-hal yang demikian itu, mudah meyakinkan diri sendiri bahwa apa yang mereka tidak inginkan sebagai benar adalah palsu atu paling kurang tidak pasti. ${ }^{47}$

Kemungkinan bahwa budi bisa salah bidik atau otak bisa salah olah misteri iman, membuat beberapa teolog yang cerdas dan saleh seperti Efrem dari Siria, Yohanes Krisostomus, Pseudo Dionisius $^{48}$ lebih berpikir tentang impossibility mengetahui dan

${ }^{47} K G K$, no. 37 membicarakan Allah. Para mistik ini mengatakan bahwa para malaikat, serafim dan kerubin saja tidak mampu mengetahui Allah apalagi seorang "debu tanah fana". Karenanya, lebih indah silence daripada sound, lebih baik tacitum daripada dictum, lebih bagus diam daripada bicara karena Allah itu tidak terkatakan - indicibile inexpressible. Kaum kecerahan ini secara implisit melihat bahwa hanya silentium mysticum memungkinkan manusia untuk mengetahui Allah benar dan menghindarkan manusia dari error cogitum.

Efrem dari Siria menegaskan bahwa: Superior di atas segala akal budi adalah Pencipta segala ciptaan berakal budi. Dia tidak bisa diduga oleh akal budi manusia bahkan tidak bisa dimengerti oleh para malaikat. Ciptaan dengan discernmentnya pun tidak layak untuk berbicara tentang Penciptanya. Jika ciptaan tidak mengenal dan memahami tuntas sumber dan asa-usulnya, bagaimana ia bisa layak untuk berbicara tentang Penciptanya? Akal budi tidak mampu untuk menjangkau ketinggian paling tinggi dari Penciptanya. Pencarian dari pencari akan tetap berada di bagian terbawah dari ketiggian itu.

Kata Yohanes Krisostomus: dunia suci saja tak bisa mengenal Allah aplagi manusia:

Kita berseru kepada Dia, Allah yang tidak terpahami, tidak dapat dikenal, tidak kelihatan, yang menihilkan semua bahasa manusia, melampaui kemampuan intelek manusia,

${ }^{48}$ Giuseppe Marco Salvati, Il Dio Della Nostra Gioa, (Napoli: Editrice Dominicana Italiana, 1995), 13-14 
tidak bisa dipahami oleh para malaikat, tersembunyi bagi para serafim, yang sukar dipahami para kerubim, tidak bisa dikontemplasikan para raja, penguasa, singkatnya tidak satu ciptaanpun mampu mengenal Allah kecuali Putera dan Roh Kudus.

"Karena sebegitu tak bisa terpikirkan oleh setiap pikiran, Satu yang ada di atas segala pikiran dan tidak bisa terkatakan oleh setiap kata, Kebaikan tertinggi di atas segala kata, maka kita memang harus diam", demikian pikiran PseudoDionisius.

Ketidakterperian radikal Allah dirumuskan Gregorius dari Nyssa sebagai berikut: "Allah adalah batu karang yang licin, terjal dan curam, di mana akal budi tak dapat menemukan tempat peristirahatan yang aman untuk mendapat pegangan atau mengangkat diri ke atas. Apapun daya upaya kita, akal budi kita tidak bisa mendekatiNya". 49

Untuk bisa pergi menghadap dan mendekati Allah, orang harus meninggalkan penalaran dan memasuki alam diam tanpa kata karena tiada orang yang pernah melihat Allah. Oleh karena itu mendeskripsikan, mendefinsikan, membuat kategori-kategori dan formulasi- formulasi mengenai Allah, memasukkan Allah ke dalam konsep-konsep sama saja dengan meremehkan Allah dan semua tindakan itu hampir berarti menghujat Allah. Ini khususnya terjadi bila orang berbicara mengenai Tritunggal yang merupakan misteri segala misteri. $^{50}$

${ }^{49}$ Stephen B. Bevans, Op. Cit., 13

${ }^{50}$ William Johnson, Op. Cit., 45
Tokoh suci Thomas à Kempis dalam nada keluh dan sesal bertanya kepada kaum rasionalistik: "apa gerangan nilainya memperbincangkan Tritunggal Mahakudus jika kamu tidak membuat Tritunggal Mahakudus itu senang dan berkenan"? 51

Seorang Taoist pernah berkata begini kepada seorang misionaris Katolik:

Kamu orang Kristen tahu terlalu banyak tahu tentang Allah.... Anda mengetahui siapa Allah, anda bisa mendefinisikan dan mendeskripsikan dan membicarakan naturaNya, atribut-atributNya, pikiranpikiranNya, rencanarencanaNya untuk keselamatan manusia dengan pola logika dan sistem berpikir filosofis yang menakjubkan. Anda mengetahui setiap Pribadi dalam Trinitas dan relasi di antara Bapa Putera dan Roh Kudus. Tentang Putera Allah yang menjadi manusia dan bisa disentuh... inipun anda jelaskan hingga detail. Dan lagi, Yesus mendirikan Gereja dan Ia menginstitusikan sakramensakramen, meninggalkan SabdaNya dan contohNya. Ini pun anda jelaskan sampai detail. Anda tahu baik apa yang harus diimani dan dilakukan supaya memperoleh keselamatan. Anda mengetahui bahwa anda bisa mengetahui apa saja sehubungan dengan misteri Allah...Tetapi saya sangat cemas.... terlalu banyak pengetahuan dan pembicaraan tentang Misteri atau Allah bisa jadi akan mengurangkan kerinduan anda dan memacetkan kekaguman anda untuk hening dan sujud sembah di hadapan Yang Sakral dan

${ }^{51}$ Ibid., 46 
lagi bisa memucatkan kegembiraan anda untuk mengarahkan diri kepada apa yang tidak bisa terkatakan dengan kata-kata. ${ }^{52}$

Dialog yang mirip terjadi pula antara santa Teresa dari Kalkuta dan seorang teolog besar India. Kata santa Teresa dari Kalkuta kepada sang teolog: "Anda begitu fasih berbicara tentang Allah dan hal itu menunjukkan betapa dekatnya anda dengan Allah". Teolog itu membalas pujian santa Teresa dari Kalkuta dengan berkata jujur:

Mungkin aku terlalu banyak tahu tentang Allah dan terlalu banyak berbicara tentang Allah tetapi sejujurnya aku terlalu sedikit berbicara dengan Allah karena aku tak mempunyai banyak waktu untuk diam dan mendengarkan Allah karena hanya dalam keheningan hati dan ketenangan akal budi, Allah berbicara dan suaraNya bisa kedengaran jelas. ${ }^{53}$

Jika orang Kristen menunjukkan lebih banyak kesabaran, kerendahan hati intelektual daripada menunjukkan bahwa mereka mengetahui lebih banyak daripada sebenarnya, maka akan terdapat lebih sedikit orang indiferentis dan ateis di dunia ini. ${ }^{54}$

Problem yang timbul dari kebiasaan membicarakan Allah dalam bahasa yang tak dimatangkan dalam kontemplasi ialah pemucatan makna hakiki misteri dan makna sejati dari misteri bisa saja terisap

52 Maria Ko, Proclaiming Jesus, The Saviour, Christ the Lord, Makalah Kongres Misi Internasional Tahun 2000 di Roma. Cetak miring itu dibuat oleh penulis untuk menegaskan kontras antara diam di hadapan Allah dan pengetahuan dan pembicaraan tentang Allah.

${ }^{53}$ T. Krispurwana Cahyadi, Jalan Kesucian Ibu Teresa, (Jakarta: Penerbit Obor, 2003), 90 ke dalam permainan bahasa heterogen atau beragam permainan kata-kata yang sulit didamaikan (logos polakos legethai) hingga kita sulit menemukan mana kosa kata eksat dan final tentang kebenaran dan Allah. ${ }^{55}$

Kebesaran Allah sesungguhnya tak bisa tertampung dalam struktur kemasukakalan manapun kecuali di dalam DiriNya sendiri. Final First tak bisa ditangkap oleh bahasa yang merupakan penemuan dan ciptaan manusia kontingens baik itu bahasa tentang keluhuran manusia maupun bahasa tentang keagungan Allah. Karena itu kita perlu berhati-hati agar jangan sampai ketika kita berbicara tentang Allah saat itu juga kita menanggalkan pakaian kemisterian Allah lalu sebagai gantinya kita mendandani Allah dengan busana manusia. ${ }^{56}$

Sekiranya ini terjadi maka ini pertanda atensi, konsentrasi atau fokus kita melonggar, kita memucatkan bahkan menghilangkan isi dan esensi kebenaran sembari kita tetap membangun ilusi bahwa kita sedang mengejar inti kebenaran. ${ }^{57}$ Tak bisa disangkal bahwa kemaha-luasan Allah itu sepertinya dikurung dalam bahasa insani saat kita membicarakan Allah atau menuliskan

\footnotetext{
${ }^{54}$ Douglas Groothius, Christianity That Counts: Being a Christian in a Non-Christian World, (Michigan: Grand Rapids, 1994), 63-65

55 Ludwig Wittgenstein, Ricerche Filosofiche, (Torino: Marieti, 1999), 21

${ }^{56}$ Lombardini - Antiseri - Baldini, C'è ancora spazio per la fede? (Milano: Rusconi, 1992), 14.

${ }^{57}$ Aleksander I. Solzhenitsyn, A World Split Apart (New York: Harper \& Row, 1978), 1.
} 
pengetahuan kita tentang Allah. Inilah realitas relativisme linguistik. ${ }^{58}$

Efek berikutnya ialah munculnya vertigo global di mana peran bahasa dalam menyuarakan kebenaran iman diragukan. Bahasa dianggap tak bisa menjadi pembawa kabar baik dan kabar benar dari Allah bagi manusia. Dalam situasi ini kebutuhan akan kebenaran dan kepastian lebih utama dan lebih sakral daripada kebutuhan akan hal lain. ${ }^{59}$

Bagi iman kristiani, bahasa bukan sekedar penemuan dan ciptaan manusia yang bersifat arbiter dan bisa direduksi menjadi faktor kultural yang kontingens melainkan bahasa adalah karunia Allah yang rasional yang dipercayakan kepada manusia, gambar dan rupaNya. Betapapun bahasa pernah terluka dan retak karena kejatuhan dan penghakiman Babel (Kej 11) namun bahasa itu telah ditebus Yesus Kristus dan kini bahasa itu tetap merupakan alat Allah di tangan manusia demi menyampaikan kabar baik ke seluruh dunia.

\section{The possible pengetahuan dan pembicaraan tentang Allah}

Melampaui kerapuhan berpikir yang terus berganti dan fluktuasi pasar paham filosofis dan teologis, ada audit (baca revelasi) Allah dan di bawah audit Allah akan ada perbaikan dan penajaman pengetahuan dan pengajaran iman kita. Pengetahuan dan pengajaran kita bisa mengalami progres berkualitas karena kelemahan kita diperbaiki oleh kebenaran Allah.

Melalui revelasi, Deus absconditus (esensiNya tak dapat dipahami,

58 James W. Sire, ChrisChrisman Goes to College: And Faces the Challenges of Relativism, Individualism and Pluralism, (Downers Grove: InterVarsity Press, 1993), 65
pikiranNya tak dapat diduga dan karyaNya dahsyat tak terselami oleh nalar manusia) membiarkan DiriNya dikenal, diketahui dan diakrabi (Deus revelatus). Melalui revelasi suci Allah menerangi akal budi manusia sehingga akal budi manusia mampu mengenalNya dan melalui hening Allah mengajarkan pengetahuan benar kepada akal budi.

\section{Allah sendiri mengajarkan pengetahuan kepada jiwa}

Thomas Aquinas menjembatani bicara dan diam, bisa tahu dan tidak bisa tahu dengan memberi teladan yakni ia berkontemplasi selama berjam-jam dan ia menekuni studi selama berjam-jam. Hatinya melekat pada Tuhan dalam doa mendalam namun tiba-tiba ia terbangun dan membicarakan suatu ajaran secara logis dan sistematis sebagai seseorang yang telah mendapatkan pencerahan spiritual dan intelektual. Ia mewartakan kepada orang lain buah kontemplasinya. Ia berkontemplasi demi membagikan (membicarakan dan mewartakan) kepada orang lain Dia yang dikontemplasikan (contemplata aliis tradere). ${ }^{60}$

Kata-kata yang disaring dalam kontemplasi itulah yang di-sharing-kan (dibicarakan). Kata-kata yang dimatangkan dalam hening menyimpan kekuatan dahsyat, bisa menerobos batas dan melintasi waktu dan ruang. Sepatah kata dua berenergi untuk hati dan budi manusia pada akhirnya enable, enoble, empower dan encourage manusia dalam situasi aktualnya. Ajaran yang menukik masuk ke dalam headandheart, tidak hanya berasal dari studi yang tekun tetapi

\footnotetext{
59 Simone Weil, The Need for Roots (Boston: Beacon, 1953), w

${ }^{60}$ William Johnson, Op. Cit., 46
} 
juga dari hati yang berdoa dan berkobarkobar cinta akan Allah.

Orang yang percaya akan Allah, biasanya tekun berbicara dengan Allah dan suka berbicara tentang Allah dan senang berakraban dengan Allah. ${ }^{61} \mathrm{Jadi}$, boleh dikatakan bahwa seorang pendoa adalah seorang teolog dan seorang teolog adalah seorang pendoa. Kata Euágrios ho Pontikós atau Evagrius Ponticus atau Evagrius Soliter (pertapa):

Jika anda seorang teolog atau seorang yang tahu tentang Allah, anda patut berdoa serius dan jika anda berdoa sungguhsungguh, maka anda adalah seorang teolog atau orang yang ahli akan Allah. Teolog adalah pendoa dan pendoa adalah teolog. Dalam doa teolog menerima dari Allah pengetahuan sejati mengenai Allah; pengetahuan ini adalah teognosis. ${ }^{62}$

"Tak seorangpun bisa menjadi teolog atau murid Kristus sejati, jika imannya tidak bercerita tentang pengalaman perjumpaan personal dengan Allah", kata Pavel Evdokimov. ${ }^{63}$

Nampak di sini ada relasi erat antara oratio et ratio sebagaimana dikatakan

${ }^{61} \mathrm{DV}$ no. 2

62 "Se sei teologo, pregherai sul serio, e se prgherai sul serio, sarai teologo. Teologo è colui che sa pregare." Lihat, Giuseppe Marco salvati, Op. Cit., 15; William Johnson, Op. Cit., 23-24; Olivier Clément, Sources. Les Mystique chrétiens des origines, (Paris: Stock, 1982), 167; George Maloney, God's Exploding Love, (New York: Alba House, 1987), 17

63 "Nessun è vero teologo o vero discepolo di Cristo, se la su fede non si contraddistingue essenzialmente come il visuto di un incontro personal con Dio." Lihat, Pavel Evdokimov, La novità dello Spirito, (Milano: Àncora, 1980), 9; Giuseppe Marco Salvati, Op. Cit., 15

64 Aimé Forest, Nos Promesses Encloses, (Paris: Beauchensne, 1985), 340: "Quand elle remonte à oleh Aimé Forest: "Ketika pikiran kembali ke dasarnya, ia dengan sendirinya menjadi religius, bukan sebagai sesuatu yang disimpulkan melainkan sebagai sesuatu yang pasti. Ia dengan sendirinya menjadi une philosophie orant - sebuah filsafat yang berdoa". ${ }^{64}$

Eksistensialis kristiani, S. Kierkegaard mengingatkan para teolog Kristen untuk menjaga adequatio antara ratio et oratio:

Seseorang yang

menyebut dirinya Kristen tetapi kalau di dalam spiritnya, ia hanya memiliki paham dan pandangan rasional tentang Allah, maka orang tersebut benar-benar tidak berdoa apapun; namun sebaliknya, seseorang itu adalah orang kafir, namun ia mengarahkan diri kepada sebuah patung berhala dengan kesadaran dan kasih tanpa batas pada berhala itu, maka orang ini benar-benar berdoa kepada Allah. ${ }^{65}$

Jadi sebelum seseorang teolog hidup berlama-lama dalam buku, ia harus hidup berlama-lama dalam doa, sebelum sebuah buku berada di perpustakan dan toko

son fondement, la pensée devient religieuse par elle-même, non d'une façion dérivée mais assurée. Elle divient par elle-même une philosophie orant." Dikutip oleh Jozef Pieniazek, dalam artikel "Soal Pemberian Dalam Terang Refleksi Metafisis," dalam Frans Ceunfin \& Felix Baghi, Mengabdi Kebenaran, (Maumere: Penerbit Ledalero, 2005), 341

65 "Se un uomo si dice cristiano ma ha nello spirito solo la nozione del vero Dio, non prega in verità; se invece quest'uomo è pagano, ma si rivolge a un idolo con la passione dell' infinito, quest'uomo prega Dio in verità." Lihat, Ignace de la Potterie, "Storia e Verità" dalam René Latourelle - Gerarld O'Collins (edd), Problemi e Prospettiva di Teologia Fundamentale, (Brescia: Queriniana, 1982²), 129 
buku, buku itu harus berada lebih dahulu di lutut: orasi, meditasi dan kontemplasi. Silentium mysticum adalah aktivitas mengetahui tanpa mengetahui. Dalam hening, Allah mengajarkan pengetahuan kepada jiwa secara diam-diam dengan menempuh jalan rahasia sehingga jiwa itu tidak mengetahui bagaimana caranya dan mengapa demikian, tanpa suara terucap dengan kata, tanpa bantuan daya jasmani atau rohani apapun, dalam alam sunyi dan ketenangan, dalam kegulitaan sehingga tak terindra dan tak tercerap oleh segala daya yang tingkatnya alami. Orang-orang yang menggeluti bidang kerohanian menyebut hening mendalam ini sebagai kegiatan mengetahui tanpa mengetahui. ${ }^{66}$

\section{Relevansi Ilahi mengiluminasi akal budi kodrati}

Di satu sisi, ada logika fenomen impossibility yakni keakraban dengan hal-hal yang serba biasa dan serba mungkin menghindarkan kita dari ketidakmungkinan. Namun di sisi lain, ada surpassabiliy yakni keyakinan bahwa kita bisa melampaui ketidak-mungkinan berkat bantuan revelasi Allah: bagi Allah tidak ada yang mustahil. Allah sendiri adalah the Possibler pengetahuan dan pembicaraan tentang DiriNya sendiri.

Menurut inisiatif bebasNya, Allah memutuskan bagi DiriNya secara ontologis untuk masuk ke dalam principium cognoscendi externum (membiarkan Diri dikenal oleh manusia). Allah sendiri yang memungkinkan dan membuat DiriNya dikenal. Supaya bisadi

${ }^{66}$ William Johnson, Op. Cit., 6

${ }^{67}$ Karl Rahner, Concise Theological Dictionary, (New York: Herder and Hereder, 1965), 144.

68 Sembari menjelaskan tema Trinitaris, Thomas Aquinas dalam Summa Theologiae I, q. 33, a. 1 mendefenisikan fundamen sebagai beirkut: "Hoc nomen principium nihil aliud significat quam id a ketahui dan diimani, magnalia Dei atau revelasi ilahi dikomunikasikan kepada manusia dan komunikasi itu terjadi dalam kisah historis. Tata realisasi revelasi ilahi itu disebut ekonomi keselamatan. ${ }^{67}$

Revelasi adalah fundamental bagi pengetahuan dan pembicaraan tentang Allah. Fundamen bukan suatu konsep tetapi sebuah prinsip. Fundamen adalah id a quo aliquidprocedit. ${ }^{68}$ Revelasi sebagai fundamen dianggap sebagai suatu evidenza sebab asal-usulnya ada dalam dirinya sendiri yang memperkenalkan dirinya sendiri sebagai sebuah novum yang tak pernah dikenal sebelumnya. Evidenza ini, dalam pengetahuan teologis, diterima melalui pengetahuan iman yang bisa mengeksplisitkannya tetapi tidak bisa mendemonstrasikannya. ${ }^{69}$

Oleh sebab itu ratio perlu memperoleh iluminasi dari revelatio supaya dengan kepastian, ratio bisa mengenal, mengetahui dan membicarakan Allah dan kebenaranNya kepada sesama dengang cara pikir manusiawi yang terbatas. ${ }^{70}$

Kepada sejumlah orang Allah mengkomunikasikan diriNya dan kehendakNya. Allah memanggil mereka supaya mereka mengenalNya dan berbicara atas namaNya tentang "proyek keselamatan Allah". Kepada orang-orang yang dipanggil itu Allah mengaruniakan fakultas ekspresif dan komunikatif, sebuah formula valid demi memberitakan pikiran dan kehendak Allah sendiri. Karena alasan ini kita akan menemukan

quo aliquid procedit; omne enim a quo aliquid procedit, quocumque modo, dicimus esse principium"

${ }^{69}$ Hans Urs Von Balthasar, Gloria. Un' Estetica Teologica, vol. I, (Milan: Jaca Book, 1987), 397491

${ }^{70} K G K$, no. $38-43$ 
bahwa kata-sabda Allah menjadi dominan atas kata-kata manusia dan hanya ada forma manusiawi yang menerjemahkan pikiran dan kehendak Allah atau Kebenaran Pertama. ${ }^{71}$

Karena anugerah pengetahuan dan perkataan itu maka kedalaman akal budi dan hati imago Dei ini, belum tentram hanya oleh silentium magnum. Homo rationale ini merasa perlu sekali untuk mendalami rahasia Allah penganugerah akal budi, kemudian dalam kepastian ratio et fides membicarakan rahasia Allah secara benar sebagai sebuah forma pewartaan Kabar Baik kepada publik. Oleh karena itu, kita menghormati dan menyembah Allah dengan dan dalam diam bukan karena kita tidak bisa sama sekali mengetahui dan membicarakan Allah melainkan karena kita menyadari bahwa tentang sebuah pencarian yang adekuat tentang Dia, sepertinya kita baru berada di tahap awal yang tidak berkesudahan. "Bagi dia yang berlari menuju Tuhan, tiada kekurangan ruang. Bagi dia yang mendaki tidak pernah ada perhentian, pergi dari awal ke awal, dengan awal yang tidak pernah berhenti". ${ }^{72}$

Kita perlu melakukan pencarian dan penyelidikan terus menerus tentang pikiran dan kehendak Allah yang sudah dibentangkan kepada kita melalui Sabda

71 Thomas Aquinas, Quaestiones disputate de Veritate, q. 18, a.3: "Est etiam quaedam locutio...interior, qua loquitur (Deus) nobis per inspirationem internam. Dicitur autem ipsa interior inspiratio locutio quaedam ad similitudinem exterioris locutionis: sicut enim in exteriori locutione proferimus ad ipsum audientem non ipsam rem quam notificare cupimus, sed signum illius rei, scilicet vocem significativam: ita Deus interius inspirando nen exhibet essentiam suam ad videndum, sed aliquod suae essentiae signum, quod est aliquis spiritualis similitudo suae sapentiae." dan ciptaan ini. Orang kristiani sesungguhnya harus percaya diri berkenaan dengan integritas intelektual imannya. Para pengikut Kristus sepatutnya tahu bahwa iman kristiani adalah iman yang rasional. Ajaran iman Katolik menegaskan bahwa Allah bisa diketahui oleh manusia melalui sinar kodrati akal budi yang telah dikaruniakan Allah kepadanya. ${ }^{73}$

Allah telah memungkinkan manusia untuk sanggup mengetahui dan membicarakan DiriNya. Allah sendiri telah menyiapkan "jalan-jalan" tertentu yang menuntun manusia untuk mengenalNya. Dan "jalan-jalan" itu bisa disebut juga "pembuktian Allah" dalam arti argumen-argumen yang cocok dan meyakinkan, yang dapat menghantar kepada kepastian. "Jalan-jalan" menuju Allah ini mempergunakan ciptaan sebagai titik tolak. ${ }^{74}$ Dari kontingensi dan keindahan alam manusia bisa mengenal yang Permanence. Kata santu Agustinus:

Tanyakanlah keindahan bumi, tanyakanlah keindahan samudera, tanyakanlah keindahan udara yang menyebar luas, tanyakanlah keindahan langit... tanyakanlah semua benda. Semuanya akan menjawab kepadamu: Lihatlah, betapa indahnya kami. Keindahan mereka adalah satu pengakuan

72 Ide Gregorius dari Nyssa yang dituangkan dalam Hom. VIII in Cant. (PG 44, 941C) dikutip oleh Yves Congar, dalam I Believe in the Holy Spirit 2 (3 vol. In 2; New York: Crossroad 1997), 77: "For the one who runs towards the Lord, there is no lack of space. The one who ascends never stops, going from beginning to beginnig, by beginnings that never cease"; Stephen B. Bevans, Op. Cit., 18

${ }^{73} K G K$, no. 36 dan 39

${ }^{74} K G K$, no. 31 
(confessio). Siapakah yang menciptakan benda-benda indah yang berubah, kalau bukan Yang Indah (Pulcher) yang tidak dapat berubah (Serm. 241. 2). ${ }^{75}$

Allah memanggil dan menuntun manusia menuju kepada apa yang primer melalui apa yang sekunder. Kehadiran Allah begitu nyata dalam kehidupan manusia takkala Allah menyatakan subyektivitasNya melalui obyektivitas (peristiwa-peristiwa konkrit). Pola revelasi adalah yang finite menyatakan yang infinite, yang terbatas menyatakan yang tak terbatas, yang obyektif mengungkapkan yang subyektif, yang biasa menguakkan misteri. "Bisa memperoleh pengetahuan samar-samar tentang hal-hal tertinggi itu lebih berarti daripada bisa memperoleh pengetahuan paling pasti tentang hal-hal yang lebih rendah". ${ }^{76}$

Manusia bisa mengenal Allah karena ia adalah "citra Allah" dan dianugerahi dengan sinar kodrati akal budi. ${ }^{77}$ Bunda Gereja berkeyakinan bahwa rasio manusia bisa mengenal dan membicarakan Allah kepada semua manusia dan bisa berbicara dengan semua manusia tentang Allah $^{78}$ walaupun pengetahuan dan pembicaraan manusia tentang Allah itu terbatas. ${ }^{79}$

Orang Kristen wajib mengetahui dan membicarakan Allah, meskipun Allah tidak terperikan. Alasannya, pertama: kita harus menghadirkan yang benar dan

${ }^{75} K G K$, no. 32

${ }^{76}$ St. Thomas Aquinas, Summa Teologiae, I, q. 1, a. 5: "et taamen minimum quod potest haberi de cognitione rerum altissimarum, desiderabilius est quam certissima cognitio quae habetur de minimis rebus."

${ }^{77} \mathrm{KGK}$, no. 36

${ }^{78} K G K$, no. 39 menghindarkan diri dari gambaran dan bayangan akan Allah yang salah sehingga kita tidak jatuh ke dalam menyembah berhala-hala; kedua, melalui pengetahuan dan pembicaraan reflektif yang tepat dan benar kita menolong sesama yang sedang dalam pergumulan mereka mencari Tuhan; ketiga, melalui pengetahuan dan pembicaraan yang tepat tentangNya, kita mewartakan, memuji dan mengagumi keagungan dan kebaikan Allah yang tidak terperikan; keempat, semua jerih payah untuk mengetahui dan membicarakan dan memikirkan Allah dimaksudkan untuk membukakan diri kita bagi misteri Allah yang transenden. Merindukan, mengejar, mendambakan Allah itu mungkin bagi kita, memikirkan dan mengungkapkanNya sampai tuntas dengan kata-kata yang layak bagiNya itu tak mungkin. ${ }^{80}$

Kita tak dapat memahami Siapa Dia kecuali Siapa yang bukan Dia. ${ }^{81}$ Pengetahuan kita tentang Allah selalu menggunakan via analogia artinya bahasa kita mengatakan lebih banyak tentang yang bukan Allah daripada tentang siapa Allah itu. ${ }^{82}$

Kita bisa mengetahui dan membicarakan Allah dengan via affirmativa: mengingat analogi entis berarti bahwa ada kemiripan antara Allah dan ciptaan: segala sesuatu yang bersifat baik pada makluk dapat juga dikenakan kepada Allah; dengan via negativa: mengingat bahwa analogi entis juga mengimplikasikan perbedaan antara

\footnotetext{
${ }^{79} K G K$, no. 40

${ }^{80}$ Niko Syukur Diester, Teologi Sistematika I, Op. Cit., 160

${ }^{81} \mathrm{KGK}$, no. 43

82 David Burrel. "Aquinas: Articulating Transcendence" dalam Excercises in Religious Understanding, (Notre Dame: University of Notre Dame, 1974), 132-133
} 
Allah dan ciptaan: segala yang ada pada ciptaan tidak berada pada Tuhan dengan cara yang sama; dengan via eminentia: apa yang baik pada makluk, tentu berada pada Tuhan dengan cara yang jauh melebihi keadaan ciptaan bahkan tidak terhingga jauhnya kelebihan itu. ${ }^{83}$

Allah memungkinkan kita untuk mengetahuiNya dan mewartakanNya namun kita harus rendah hati mengatakan bahwa bagaimanapun juga tetap ada jarak epistemik antara manusia dan Allah. Allah bisa mengetahui diri kita sampai tuntas (Mzm 139:1-24) namun kita tidak mampu mengenal secara tuntas pikiran Allah (Roma 11:34; 1Kor 2:16). Jarak epistemik itu dialami oleh Thomas Aquinas: "Saya tidak bisa terus (menulis) lagi.... semua yang sudah saya tulis tentang Dia terlihat seperti jerami belaka dibandingkan dengan apa yang saya lihat dan apa yang diwahyukan kepada saya di dalam Misa Kudus". ${ }^{84}$

Silentium mysticum (diam mengagumi Allah) harus menjadi titik tiba sebuah pencarian panjang akan Allah. Hening harus menjadi buah dari sebuah pilihan sadar dan matang di akhir sebuah usaha serius pencarian akan Allah dan bukan sebuah penolakan aprioristik. Ujung pangkal dari sebuah aktivitas dan ketekunan mencari ialah tenang mendalam di depan Tiga yang adalah communio Bapa, Putera dan Roh Kudus. Pada momen ini biar Hening itu yang

${ }^{83}$ Thomas Aquinas, Summa Theologiae, I, q. 13, a. 2 et a. 5; Wlliam Johnston, Op. Cit., 48

${ }^{84}$ James A. Weisheipl, Friar Thomas d'Aquino, (New York: Doubleday, 1974), 321322; Thomas F. O'Meara, Thomas Aquinas: Theologian, (Notre Dame: University of Notre Dame Press, 1997), 31.

${ }^{85}$ Abraham J. Heschel, L'Uomo non è solo, (Milano: Edizione Ghibli, 1970), 135; Giuseppe Marco Salvati, Op. Cit., 20 berbicara dan kita memasang telinga, membuka mata sukma untuk menangkap pesan dan pesonaNya. Di hening hati seorang "debu tanah" boleh temu pandang dengan Hening, boleh wawancara denganNya tanpa kata dalam selubung iman.

\section{Logika, soteriologika, sikap cautela}

Sebelum kita menjadikanAllah sebagai Dia yang kita bicarakan, Allah telah lebih dahulu adalah Dia yang berbicara kepada kita dan menerangi akal budi kita. Kita mendengarkan SabdaNya supaya kita bisa mewartakan SabdaNya walau dalam kata-kata yang terbatas. Kitab Suci terutama bukan visi manusia tentang Allah melainkan visi Allah tentang keselamatan manusia. Kitab Suci bukan teologi tentang manusia melainkan antropologi dari Allah yang berurusan dengan manusia dan seluk beluk hidup manusia. ${ }^{85}$

Jadi berbicara tentang Allah adalah berbicara tentang diri kita sebagai creation yang membutuhkan salvation. Orang yang berbicara tentang Allah mestinya tak terpaku dengan misterio logico melainkan patut terpanah dengan misterio soteriologico. ${ }^{86}$ Pengetahuan akan Allah itu keharusan demi memahami secara tepat siapa diri kita sebagai creazione yang membutuhkan redenzione. ${ }^{87}$ Pengetahuan filosofis saja tidak cukup untuk menjamin keselamatan

\footnotetext{
${ }^{86}$ Giuseppe Marco Salvati, Op. Cit., 16
}

${ }^{87}$ Thomas Aquinas, Summa Theologiae, I, q. 32, a. 1, ad 3um: "dicendum quod cognitio divinarum Personarum fuit necessaria nobis dupliciter. Uno modo, ad recte sentiendum de creatione rerum; alio modo, et principalius, ad recte sentiendum de salutis generis humanum, quae perficitur per Filium incarnatum et per donum Spiritus Sancti." 
manusia. Keselamatan manusia meminta sebuah sacra doctrina sebagai sebuah necessarium yang bisa menuntun manusia menuju kepada kehidupan akhir. $^{88}$

Misteri Allah berelasi dengan misteri soteriologico, maka pembicaraan kita tentang Allah, terkristalisasi di dalam diri Yesus Kristus, puncak dan kepenuhan Revelasi. Kekristenan adalah Yesus Kristus. Pribadi dan karyaNya merupakan wadas di atasnya iman Kristen didirikan. Jika Ia bukan seseorang yang Ia katakan, dan Ia tidak melakukan apa yang Ia katakan sesuai dengan tujuan kedatanganNya, dasarnya pasti rusak dan keseluruhan suprastrukturnya akan runtuh. Mencabut Kristus dari kekristenan berarti kenihilan absolut dalam kekeristenan. Kristus adalah inti kekristenan dan hal lainnya adalah kelilingnya. ${ }^{89}$

Kristus sambil merevelasikan Allah dalam DiriNya, Ia juga pada saat yang sama merevelasikan manusia kepada manusia yakni manusia adalah imago Dei dan memberitakan kepada manusia tujuan akhir hidup yakni berpartisipasi di dalam kehidupan ilahi, manusia menjadi pribadi bersama dengan Pribadi-Pribadi Ilahi, berkomunitas dengan Trinitas sebagai sebuah koinōnia kudus. Misteri Trinitas memang tidak mudah dipahami,

88 Thomas Aquinas, Summa Theologiae, I, q. 1, a. 1: "homo ordinatur ad Deum sicut ad quendam finem qui comprehensionem rationis excedit, secundum illud Isaiae 64, [4]: oculus non vidit Deus absque te, quae praeparasti diligentibus te. Finem autem oportet esse praecognitum hominibus, qui suas intentiones et actiones debent ordinare in finem. Unde necessarium fuit homini ad salutem, quod ei nota fierent quaedam per revelationem divinam, quae rationem humanam excedunt."

89 John Stott, Basic Christianity, (Grand Rapids: Eerdmans, 1958), 21 karena itu misteri Trinitas harus dibicarakan dengan sikap cautela et modestia. ${ }^{90}$ Atau seperti ajakan suci Konsili Vatikan I bagi kita untuk membangun sikap: sedulo: membicarakan Trinitas dengan penuh perhatian dan hati-hati dalam memakai intelligensi; pie: membicarakan Trinitas dengan sikap spiritual yang terarah pada perjumpaan personal dengan Allah yang keluar dari misteriNya "untuk berbicara kepada manusia seperti berbicara kepada para sahabat" dan sobrie: membicarakan Allah dengan diskresi mendalam sambil menyadari keterbatasan diri dan perbedaan kualitatif tak terbatas antara Allah dan manusia. ${ }^{91}$

\section{Kesimpulan}

Bercermin pada uraian di atas, kita bisa menyimpulkan bahwa ada dua macam pengetahuan. Yang pertama ialah pengetahuan yang dicurahkan. Pengetahuan ini dicurahkan oleh Roh Kudus ke dalam hati orang-orang pilihan Allah. Allah mengajarkan pengetahuan kepada jiwa mereka sine medio - tanpa media penalaran dari makluk terindra. ${ }^{92}$ Pengetahuan ini masuk dalam spcies infusa (dicurahkan) melalui silentium mysticum atau kontemplasi.

90 Thomas Aquinas, Summa Teologiae, I, q. 31, a 2: “...cum de Trinitate loquimur cum cautela et modestia est agendum".

${ }^{91}$ Giuseppe Marco Salvati, Op. Cit., 18

92 Leluhur kita yang pertama dalam keadaan kodrat aslinya adalah manusia kontemplatif. Leluhur kita yang pertama mengtahui Allah 'sine medio' - "non-per medium argumenttationis ex creaturibus sensibilibus. Lihat Thomas Aquinas, II Sent., d. 223, q.2 art 1, ad 1; William Johnston, Op. Cit., 70-71 dan footnote 16 
Yang kedua ialah pengetahuan yang diperoleh melalui proses pencarian ilmiah: memikirkan dan mengetahui. Menurut Thomas Aquinas di dalam akal budi tak ada sesuatu yang sebelumnya tak ada di dalam indra. ${ }^{93}$ Pengetahuan jenis ini berasal dari indra luar, masuk ke indra dalam dan disampaikan ke akal budi oleh apa yang disebut species acquisita.

\section{Daftar pustaka}

Konsili Vatikan II, Gudium et Spes, Konstitusi Pastoral tentang Gereja di Dunia Dewasa Ini (tanggal 7 bulan Desember 1965), dalam R Hardawirjana (pener.), Dokumen Konsili Vatikan II, Jakarta: Obor, 1993.

Paus Paulus VI, Evangelli Nuntiandi, Anjuran Apostoli (tanggal 8 Desember tahun 1975) dalam Seri Dokumen Gerejawi 6, Jakarta:

Departemen Dokumentasi dan Penerangan KWI, 2005.

Yohanes Paulus II (Promulgator), Katekismus Gereja Katolik, diterjemahkan oleh Herman Embuiru, Katekismus Gereja Katolik, Ende: Percetakan Arnoldus, 1995.

Abraham J. Heschel, L'Uomo non è solo, Milano: Edizione Ghibli, 1970.

Agustinus, La Città di Dio, Roma: Città Nouva Editrice, 1997.

Aimé Forest, Nos Promesses Encloses, Paris: Beauchensne, 1985.

Aleksander I. Solzhenitsyn, A World Split Apart, New York: Harper \& Row, 1978.

\footnotetext{
93 William Johnston, Ibid., 70 dan footnote 14: "nihil est in intellectu quod non fuit prius in sensu"
}

Bernard Lonergan, Insight: A Study of Human Understanding, Edited by Frederick E. Corwe and Robert M. Doran, Toronto: University Toronto Press, 1992.

Blaise Pascal, Pensées, diedit oleh Alban J. Krailsheimer, New York: Penguin, 1966.

-------, Verso l'Infinito di Dio. Brani Scelti dai Pensieri e da altri Scriti. Terjemahan,

Introduksi dan Pilihan Lirik oleh Giuliano Vigini, Milano: Paoline Editoriale Libri, 1997.

Dario Antiseri, Quale Ragione, Milano: Rafaello Cortina Editore, 2001.

David Burrel, Excercises in Religious Understanding, Notre Dame: University of Notre Dame, 1974.

David L. Edwards, Christianity: The First Two Thousand Years, Maryknoll, New York: Orbis Books, 1997.

Douglas Groothius, Christianity That Counts: Being a Christian in a Non-Christian World, Michigan: Grand Rapids, 1994.

Edward O. Wilson, Consilience: The Unity of Knowledge, New York: Knopf, 1988.

Frans Ceunfin \& Felix Baghi, Mengabdi Kebenaran, Maumere: Penerbit Ledalero, 2005.

Franz Magnis-Suseno, Menalar Tuhan, Yogyakarta: Kanisius, 2006.

Fung Yu - Lan dalam Sejarah Filsafat Cina, Yogyakarta: Pustaka Pelajar, 2007.

George Maloney, God's Exploding Love, New York: Alba House, 1987. 
George Steiner, Language and Silence, London: SCM Press, 1967.

Giovanni Marchesi, La Cristologia Trinitaria, Cristologia

Trinitaria di Hans Urs Von

Balthasar, Brescia: Editrice Queriniana, 1997.

Giuseppe Marco Salvati, Il Dio Della Nostra Gioa, Napoli: Editrice Dominicana Italiana, 1995.

Hans Urs Von Balthasar, Gloria. Un' Estetica Teologica, vol. I, Milan: Jaca Book, 1987.

--------, Gloria. Un’ Estetica Teologica, vol. I, Milan: Jaca Book, 1987.

Immanuel Kant, what is Enlightenment? translated and edited by Lewis White Beck Indianapolis: Bobbs-Merrill, 1959.

James A. Weisheipl, Friar Thomas d'Aquino, New York: Doubleday, 1974.

James W. Sire, The Universe Next Door, Edisi 3, Downers Grove, III: InterVarsity Press, 1997.

James W. Sire, ChrisChrisman Goes to College: And Faces the Challenges of Relativism, Individualism and Pluralism, Downers Grove: InterVarsity Press, 1993.

John Stott, Basic Christianity, Grand Rapids: Eerdmans, 1958.

Joseph H.P. Wong, Logos-Symbol in the Christology of Karl Rahner, Roma: Libreria Ateneo Salesiano, 1984.

Josepho Alberigo et alii (curantibus), Conciliorum Oecumenicorum Decreta, Bologna: Istituto Scienze Religiose, 1973.

Julio Terán Dutari, Christentum und Metaphysik. Das Verständtnis Beider Nach der Analogielehre Erich Pryzwara, München, 1973.
Karl Rahner, Concise Theological Dictionary, New York: Herder and Hereder, 1965.

Kosuke Koyama, Water Buffalo Theology, New York: Maryknoll, Orbis Books, 1999.

Ludwig Wittgenstein, Ricerche Filosofiche, Torino: Marieti, 1999.

Lombardini - Antiseri - Baldini, C'è ancora spazio per la fede? Milano: Rusconi, 1992.

Maurice Merleau-Ponty, Signes, Paris: Gallimard, 1960.

Olivier Clément, Sources. Les Mystique chrétiens des origines, Paris: Stock, 1982.

Paul Budi Kleden dan Adrianus Sunarko (Eds), Dialektika Sekularisasi, Diskusi Habermans-Ratzinger dan Tanggapan, Maumere:

Penerbit Ledalero dan Penerbit Lamalera, 2010.

Paul Budi Kleden dan Robert Mirsel (ed.), Menerobos Batas, Merobohkan Prasangka, Jilid 2, Maumere: Penerbit Ledalero 2011.

Pavel Evdokimov, La novità dello Spirito, Milano: Àncora, 1980.

Pius Budiwijaya, Tuhan Memegangku, Yogyakarta: Penerbit Kanisius, 1989.

Rasiah S. Sugirtharajah, (ed.), Voices from the Margin: Interpreting the Bible in the Third World, New York: Orbis Books, Maryknoll, 1991.

René Latourelle, Theology, Science of Salvation, New York: Alba House, 1969.

René Latourelle - Gerarld O'Collins (ed.), Problemi e Prospettiva di Teologia Fundamentale, Brescia: Queriniana, 1982. 
Robert J. Schreiter, Constructing Local Theologies, New York: Orbis Books, 1985.

Robert Hardawirjana (penerj.), Dokumen Konsili Vatikan II, Jakarta: Obor, 1993.

Ronald H. Nash, Iman dan Akal Budi, Surabaya: Penerbit

Momentum, 1988.

Ronaldo Muños, The God of Christians, New York: Maryknoll, Orbis Books, 1990.

Samuel Enoch. Stumpf, Philosophy: History \& Problems, New York: McGraw-Hill, Inc, 1989.

Simone Weil, The Need for Roots, Boston: Beacon, 1953.

Stephen B. Bevans, Teologi Dalam Perspektif Global, Maumere: Penerbit Ledalero, 2010.

Theo Huijbers, Mencari Allah, Yogyakarta: Penerbit Kanisius, 1992.

Thomas Aquinas, Summa Theologiae, Milano: Edizione Paoline, 1998.

Thomas F. O'Meara, Thomas Aquinas: Theologian, Notre Dame: University of Notre Dame Press, 1997.

T. Krispurwana Cahyadi, Jalan Kesucian Ibu Teresa, Jakarta: Penerbit Obor, 2003.
Thomas Stearns Eliot, Murder in the Cathedral, New York: Brace \& World, Harcourt, 1963.

William J. Hill, The Three Personal God, Washington: The Catholic University of America Press, 1982.

William Johnston, Teologi Misitk, Yogyakarta: Penerbit Kanisius, 2001.

William A. Kaschmitter, The Spirituality of the Catholic Church, Texas: Lumen Christi Press 1982.

Yves Congar, dalam I Believe in the Holy Spirit 2, (3 vol. In 2), New York: Crossroad 1997.

Luciano Pacomio - Giuseppe Occhipinti (a cura di), Lexicon, Dizionario dei Teologi, Milano, Piemme, 1998.

Giovanni Marchesi, "Il mistero di Dio nella riflessione teologica di Jurgen Moltman" dalam Civiltà Cattolica III, 1985.

Maria Ko, Proclaiming Jesus, The Saviour, Christ the Lord, Makalah Konggres Misi Internasional Tahun 2000 di Roma.

https://id.wikipedia.org/wiki/Hidup_yan g_tak_te ruji_tak_layak_dijalani. Diakses 29 Agustus 2020, pukul 21.35 